\title{
Seasonal contributions of phytoplankton and fecal pellets to the organic carbon sinking flux in the North Water (northern Baffin Bay)
}

\author{
Gitane Caron ${ }^{1,3}$, Christine Michel ${ }^{2}$, Michel Gosselin ${ }^{1, *}$ \\ ${ }^{1}$ Institut des Sciences de la Mer (ISMER), Université du Québec à Rimouski, 310 Allée des Ursulines, Rimouski, \\ Québec G5L 3A1, Canada \\ ${ }^{2}$ Freshwater Institute, Fisheries and Oceans Canada, 501 University Crescent, Winnipeg, Manitoba R3T 2N6, Canada \\ ${ }^{3}$ Present address: Département de Biologie, Université Laval, Sainte-Foy, Québec G1K 7P4, Canada
}

\begin{abstract}
The downward export of organic material was assessed during the productive period (late spring to early autumn) in the North Water polynya area (NOW; northern Baffin Bay). Freedrifting short-term particle interceptor traps were deployed at 3 depths below the euphotic zone (50, 100 and $150 \mathrm{~m}$ ) for 12 to $24 \mathrm{~h}$ at 19 stations from June to July in 1998 and at 12 stations during August and September in 1999. The sinking material was analyzed for particulate organic carbon (POC) and pigments (chlorophyll $a$ and pheopigments), and for phytoplankton and fecal pellet enumerations. POC and pigment sinking fluxes at $50 \mathrm{~m}$ averaged 337 and $8 \mathrm{mg} \mathrm{m}^{-2} \mathrm{~d}^{-1}$, respectively. The maximum sinking fluxes of organic matter (ca. $554 \mathrm{mg} \mathrm{C} \mathrm{m}^{-2} \mathrm{~d}^{-1}$ and $14 \mathrm{mg}$ pigments $\mathrm{m}^{-2} \mathrm{~d}^{-1}$ ) were observed in June, after which they decreased and remained relatively constant (ca. 219 to $240 \mathrm{mg} \mathrm{C} \mathrm{m}^{-2} \mathrm{~d}^{-1}$ and 3.9 to $4.1 \mathrm{mg}$ pigments $\mathrm{m}^{-2} \mathrm{~d}^{-1}$ ). Phytoplankton carbon flux decreased while fecal carbon flux increased during the study. In June, intact diatom cells and fecal pellets made up 50 and $4 \%$ of the total POC sinking flux, respectively. During the following months, they made up $\leq 10 \%$ (diatoms) and 30 to $50 \%$ (fecal pellets) of the total POC flux. A rapid increase in sinking cell numbers and fecal pellets at the end of the sampling season points to a late summer-early autumn bloom in the NOW. The dominant pathway of carbon cycling changed during the study, from export in spring to retention afterwards. From July on, the retention of particulate organic matter in the upper $100 \mathrm{~m}$ of the water column was favored by the low sinking velocities of POC and chlorophyll $a$, which averaged $\leq 1.3 \mathrm{~m} \mathrm{~d}^{-1}$. Over the whole sampling period, $35 \%$ of the particulate phytoplankton production was exported through sinking, while $65 \%$ was recycled or remained suspended in the euphotic zone. The organic carbon produced in the euphotic zone was, thus, mainly available to pelagic grazers rather than being exported to the benthic community. These results are in agreement with the abundance of higher trophic level pelagic organisms observed in this region.
\end{abstract}

KEY WORDS: Vertical flux · Sinking rate $\cdot$ Particulate organic carbon $\cdot$ Phytoplankton $\cdot$ Fecal pellets · North Water polynya

Resale or republication not permitted without written consent of the publisher

\section{INTRODUCTION}

According to global circulation models, global warming will continue over the next decades (Stouffer et al. 1989, Shindell et al. 1999, Flato et al. 2000, Kamenkovich et al. 2002). During the next century, the global temperature is expected to increase from 1.4 to $5.8^{\circ} \mathrm{C}$ (IPCC 2001). This warming will be manifested first and amplified in the polar regions, particularly in the Arctic (Stouffer et al. 1989, Shindell et al. 1999, Flato et al. 2000, IPCC 2001, Kamenkovich et al. 2002). The temperature rise may increase the size and number of polynyas (areas of open water, partially or totally surrounded by sea ice; Smith et al. 1990) and, conse- 
quently, enhance the activity of the biological pump which is the conversion of euphotic zone $\mathrm{CO}_{2}$ into phytoplankton carbon and its export to depth (Volk \& Hoffert 1985). This positive feedback, in the short term, may help to draw down the excess atmospheric $\mathrm{CO}_{2}$. However, before validating this scenario, a better knowledge of the actual sedimentation cycle of particulate organic matter in polynyas is needed.

Traditionally, there are 2 pathways to describe organic carbon sedimentation in the water column. On the one hand, phytoplankton carbon can be transferred to the higher trophic level by zooplankton grazing (Legendre 1990). Part of this carbon is then used by the organisms, while another part may be exported in depth under fecal pellet form (Pilskaln \& Honjo 1987). On the other hand, the primary production that is not used by the pelagic herbivores can be exported out of the euphotic zone through sedimentation of intact cells (Legendre \& Le Fèvre 1991). The first pathway, called the retention chain by Peinert et al. (1989), favors transfer to the pelagic ecosystem, while the second pathway, the export chain (Peinert et al. 1989), leads to food input to the benthic community and potentially to carbon sequestration in the sediments. The carbon reaching the seafloor has to be replaced by a new supply of atmospheric carbon in the surface waters to maintain the equilibrium of the partial pressure of $\mathrm{CO}_{2}$ between the air and the sea (Volk \& Hoffert 1985). In Arctic regions, polynyas are considered to be important atmospheric carbon sinks because of their high primary productivity (Stirling 1980, 1997, Smith \& Rigby 1981, Klein et al. 2002), their large sinking export (Hargrave et al. 2002, Michel et al. 2002) and potential sequestration of carbon (Yager et al. 1995, Miller et al. 2002).

The North Water polynya (NOW), located north of Baffin Bay between Ellesmere Island and Greenland, opens around the end of March (Dunbar 1969, Smith \& Rigby 1981). Its northern limit is formed by an ice bridge in the north of Smith Sound, which blocks the entrance of drifting arctic ice in the polynya (Dunbar 1969, Smith \& Rigby 1981, Barber et al. 2001). The polynya disappears stricto sensu in July after the ice bridge breaks up. The NOW is the largest recurring polynya in the Canadian Arctic and is considered by some to be the most productive region in the Northern Hemisphere (Stirling 1980, 1997). The total and new phytoplankton production in this region are the highest ever reported in the Arctic (Klein et al. 2002, Tremblay et al. 2002a). The phytoplankton growing period in the NOW is long compared to adjacent ice covered areas and takes place from mid-April to the end of September (Klein et al. 2002, Tremblay et al. 2002a). In the first part of the productive period (between April and July), carbon from phytoplankton is mostly exported out of the euphotic zone in June, with a high dominance of intact diatom cells and empty frustules (Michel et al. 2002). Due to both biological and advective export, the NOW region could be a net sink of atmospheric carbon (Miller et al. 2002).

In addition, the NOW area supports a large population of higher trophic level organisms, such as fish, mammals and birds (Stirling 1980, 1997, Brown \& Nettleship 1981, Karnovsky \& Hunt 2002, Ringuette et al. 2002, Lee et al. 2003). In a recent study, Mei et al. (2003) estimated that $81 \%$ of the particulate production of large phytoplankton ( $>5 \mu \mathrm{m})$ from April to July was transferred to metazoans through the herbivorous food web while only $19 \%$ was exported to deep water by sinking. The particulate production of small phytoplankton $(0.7$ to $5 \mu \mathrm{m})$, which was only $19 \%$ of the total particulate production, was mostly channeled to the microbial food web, since little was lost to depth (Mei et al. 2003). In addition, Hamel et al. (2002) estimated that the burial flux of organic carbon in the southeastern part of the NOW region corresponds to $4-6 \%$ of the annual primary production in the euphotic zone. These results suggest that a large part of the primary production of the NOW is retained in the surface waters.

This study, undertaken within the framework of the International North Water Polynya Study Project, aimed to extend our knowledge of the sedimentation cycle of particulate organic matter, especially carbon, in the NOW area from June to the beginning of autumn. The main objectives were: (1) to describe the seasonal and vertical patterns of particulate organic matter sedimentation and (2) to assess the trends in the phytoplankton and fecal pellet contribution to the organic carbon fluxes during the productive period in the NOW. To our knowledge, this study is the first to cover a 4 month sampling of free-drifting particle interceptor traps in the Arctic.

\section{MATERIALS AND METHODS}

Sampling and analyses. Sampling was carried out in the NOW region from 5 June to 20 July 1998 and from 27 August to 1 October 1999 on the ice-breaker CCGS 'Pierre Radisson'. Free-drifting particle interceptor traps were deployed at 3 depths $(50,100$ and $150 \mathrm{~m})$ at a total of 31 stations (19 stations were visited in 1998 and 12 stations in 1999). The location of sampling stations is shown in Fig. 1. Details on the position, duration and the movement of the moorings deployed in 1999 are presented in Table 1; details for the 1998 moorings can be found in Michel et al. (2002).

At each station, particle interceptor traps were deployed from the ship for 12 to $24 \mathrm{~h}$, except at Stn C33 in 1998 (36 h) and at Stn D1 in 1999 (6 h). The traps 
were Plexiglas cylinders with an internal diameter of $6.5 \mathrm{~cm}$ and an aspect ratio (height:diameter) of 9. In order to collect enough material for the analyses, a series of cylinders (4 to 6) were installed on the trap line, one below the other and centered around the mooring depth.

Particle interceptor trap deployments and handling were performed according to JGOFS protocols (1996) and recommendations from Gardner (2000). Freedrifting traps were surface-tethered with a series of small floats to minimize vertical motion on the trap line. Before deployment, the particle interceptor traps were filled with Whatman GF/F-filtered seawater and salt was added to increase the salinity by ca. 5 PSU and to create a dense layer in the traps. No poison or preservative was used during the deployments. Upon recovery, the traps were covered with a tight lid and placed vertically in a dark cold chamber $\left(0^{\circ} \mathrm{C}\right)$ for $8 \mathrm{~h}$. After that sedimentation period, the supernatant was carefully removed and the bottom volume of the trap (ca. $500 \mathrm{ml}$ ) was kept for subsequent analyses. The traps were carefully rinsed with distilled water between each deployment.

Volumes from traps deployed within each depth horizon were combined into a single sample that was used for biochemical analyses. Trap samples were prescreened through a $500 \mu \mathrm{m}$ Nitex mesh before subsamples were taken for the analyses. Very few swimmers, mostly copepods, were observed during this procedure.

Total pigments were filtered in duplicate on $25 \mathrm{~mm}$ Whatman GF/F glass fiber filters, while the $>5 \mu \mathrm{m}$ fraction was filtered in duplicate on $25 \mathrm{~mm}$ Poretics polycarbonate membranes with a nominal pore size of $5 \mu \mathrm{m}$. Standard fluorometric determination of chlorophyll $a$ ( $\operatorname{chl} a$ ) and pheopigments was carried out on board the ship, using a 10-005R Turner Designs fluorometer. This

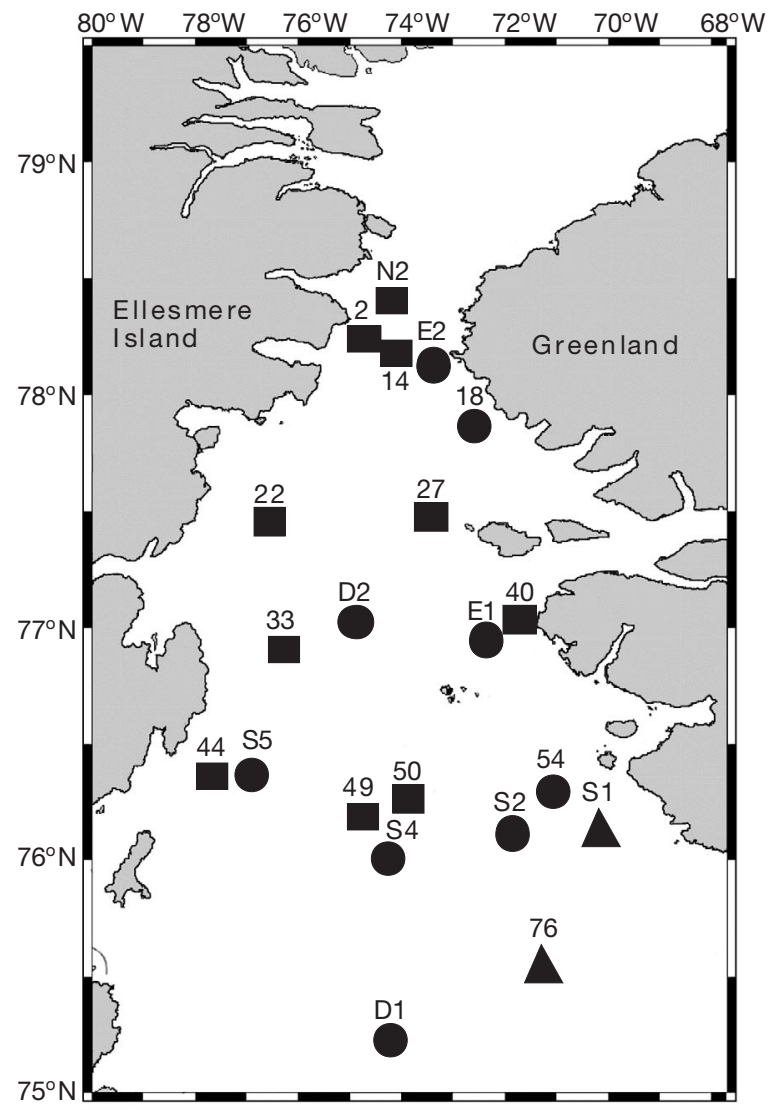

Fig. 1. Location of the sampling stations in the North Water region in $1998(\boldsymbol{\square}), 1999(\mathbf{\Delta})$ and during both years $(\bullet)$

analysis was done on the duplicate subsamples after $24 \mathrm{~h}$ extraction in $90 \%$ acetone at $4{ }^{\circ} \mathrm{C}$ in the dark (Parsons et al. 1984). Determination of particulate organic carbon (POC) was performed in duplicate on subsamples filtered on pre-combusted (at $500^{\circ} \mathrm{C}$ for $5 \mathrm{~h}$ ) $21 \mathrm{~mm}$

Table 1. Characteristics of the free-drifting particle interceptor trap moorings in the North Water in 1999

\begin{tabular}{|c|c|c|c|c|c|c|c|c|c|c|}
\hline \multirow[t]{2}{*}{ Station } & \multirow[t]{2}{*}{ Leg } & \multirow[t]{2}{*}{ Date in } & \multirow{2}{*}{$\begin{array}{l}\text { Duration } \\
\text { (d) }\end{array}$} & \multicolumn{2}{|c|}{ Deployment } & \multicolumn{2}{|c|}{ Recovery } & \multirow{2}{*}{$\begin{array}{l}\text { Distance } \\
\text { travelled } \\
\quad(\mathrm{km})\end{array}$} & \multirow{2}{*}{$\begin{array}{c}\text { Average } \\
\text { speed } \\
\left(\mathrm{cm} \mathrm{s}^{-1}\right)\end{array}$} & \multirow{2}{*}{$\begin{array}{c}\text { Water } \\
\text { depth } \\
(\mathrm{m})\end{array}$} \\
\hline & & & & $\begin{array}{l}\text { Latitude } \\
\left({ }^{\circ} \mathrm{N}\right)\end{array}$ & $\begin{array}{c}\text { Longitude } \\
\left({ }^{\circ} \mathrm{W}\right)\end{array}$ & $\begin{array}{l}\text { Latitude } \\
\left({ }^{\circ} \mathrm{N}\right)\end{array}$ & $\begin{array}{l}\text { Longitude } \\
\left({ }^{\circ} \mathrm{W}\right)\end{array}$ & & & \\
\hline D1 & 1 & $27 \mathrm{Aug}$ & 0.34 & $75^{\circ} 16.8^{\prime}$ & $75^{\circ} 09.5^{\prime}$ & $75^{\circ} 17.7^{\prime}$ & $75^{\circ} 18.7^{\prime}$ & 4.7 & 15.9 & 439 \\
\hline $\mathrm{S} 4$ & 1 & 29 Aug & 0.93 & $76^{\circ} 13.4^{\prime}$ & $74^{\circ} 11.5^{\prime}$ & $76^{\circ} 10.2^{\prime}$ & $74^{\circ} 18.4^{\prime}$ & 6.7 & 8.3 & 440 \\
\hline S5 & 1 & 30 Aug & 0.52 & $76^{\circ} 24.4^{\prime}$ & $77^{\circ} 23.2^{\prime}$ & $76^{\circ} 26.3^{\prime}$ & $77^{\circ} 30.2^{\prime}$ & 4.7 & 10.4 & 321 \\
\hline D2 & 1 & $1 \mathrm{Sep}$ & 0.88 & $76^{\circ} 54.8^{\prime}$ & $75^{\circ} 08.2^{\prime}$ & $76^{\circ} 41.2^{\prime}$ & $75^{\circ} 49.0^{\prime}$ & 30.5 & 40.2 & 523 \\
\hline E2 & 1 & $3 \mathrm{Sep}$ & 0.93 & $78^{\circ} 01.9^{\prime}$ & $73^{\circ} 21.1^{\prime}$ & $78^{\circ} 01.8^{\prime}$ & $73^{\circ} 21.6^{\prime}$ & 0.0 & 0.0 & 259 \\
\hline E1 & 1 & $6 \mathrm{Sep}$ & 0.97 & $76^{\circ} 59.7^{\prime}$ & $72^{\circ} 26.7^{\prime}$ & $76^{\circ} 58.4^{\prime}$ & $72^{\circ} 16.9^{\prime}$ & 4.8 & 5.7 & 537 \\
\hline $\mathrm{S} 2$ & 1 & $8 \mathrm{Sep}$ & 0.92 & $76^{\circ} 18.1^{\prime}$ & $72^{\circ} 00.4^{\prime}$ & $76^{\circ} 15.8^{\prime}$ & $71^{\circ} 51.4^{\prime}$ & 5.8 & 7.3 & 560 \\
\hline S1 & 1 & 9 Sep & 0.52 & $76^{\circ} 18.1^{\prime}$ & $70^{\circ} 27.3^{\prime}$ & $76^{\circ} 18.4^{\prime}$ & $70^{\circ} 28.4^{\prime}$ & 0.9 & 2.0 & 264 \\
\hline S4 & 1 & $10 \mathrm{Sep}$ & 0.72 & $76^{\circ} 15.6^{\prime}$ & $74^{\circ} 14.3^{\prime}$ & $76^{\circ} 16.8^{\prime}$ & $74^{\circ} 09.4^{\prime}$ & 3.1 & 5.0 & 436 \\
\hline P-54 & 2 & $20 \mathrm{Sep}$ & 0.80 & $76^{\circ} 16.5^{\prime}$ & $71^{\circ} 52.3^{\prime}$ & $76^{\circ} 16.7^{\prime}$ & $71^{\circ} 49.8^{\prime}$ & 1.3 & 1.8 & 556 \\
\hline P-18 & 2 & $24 \mathrm{Sep}$ & 0.47 & $77^{\circ} 49.3^{\prime}$ & $73^{\circ} 09.6^{\prime}$ & $77^{\circ} 40.3^{\prime}$ & $73^{\circ} 25.5^{\prime}$ & 17.8 & 43.8 & 163 \\
\hline P-76 & 2 & $1 \mathrm{Oct}$ & 0.93 & $75^{\circ} 36.2^{\prime}$ & $70^{\circ} 46.9^{\prime}$ & $75^{\circ} 36.4^{\prime}$ & $70^{\circ} 47.7^{\prime}$ & 0.0 & 0.0 & 535 \\
\hline
\end{tabular}


Whatman GF/F filters. The samples were stored frozen at $-80^{\circ} \mathrm{C}$ until analysis. After being dried at $60^{\circ} \mathrm{C}$ for $24 \mathrm{~h}$, samples were pelletized and analyzed on a Perkin-Elmer Model $2400 \mathrm{CHN}$ analyzer.

Subsamples from the $50 \mathrm{~m}$ depth horizon were fixed with acidic lugol (Parsons et al. 1984) for later identification and enumeration of phytoplankton cells with an inverted microscope, according to the Utermöhl technique (Lund et al. 1958). A minimum of 400 cells per sample were counted. Total cell volume was estimated for each sample using average cell volumes determined for the most abundant species together with the
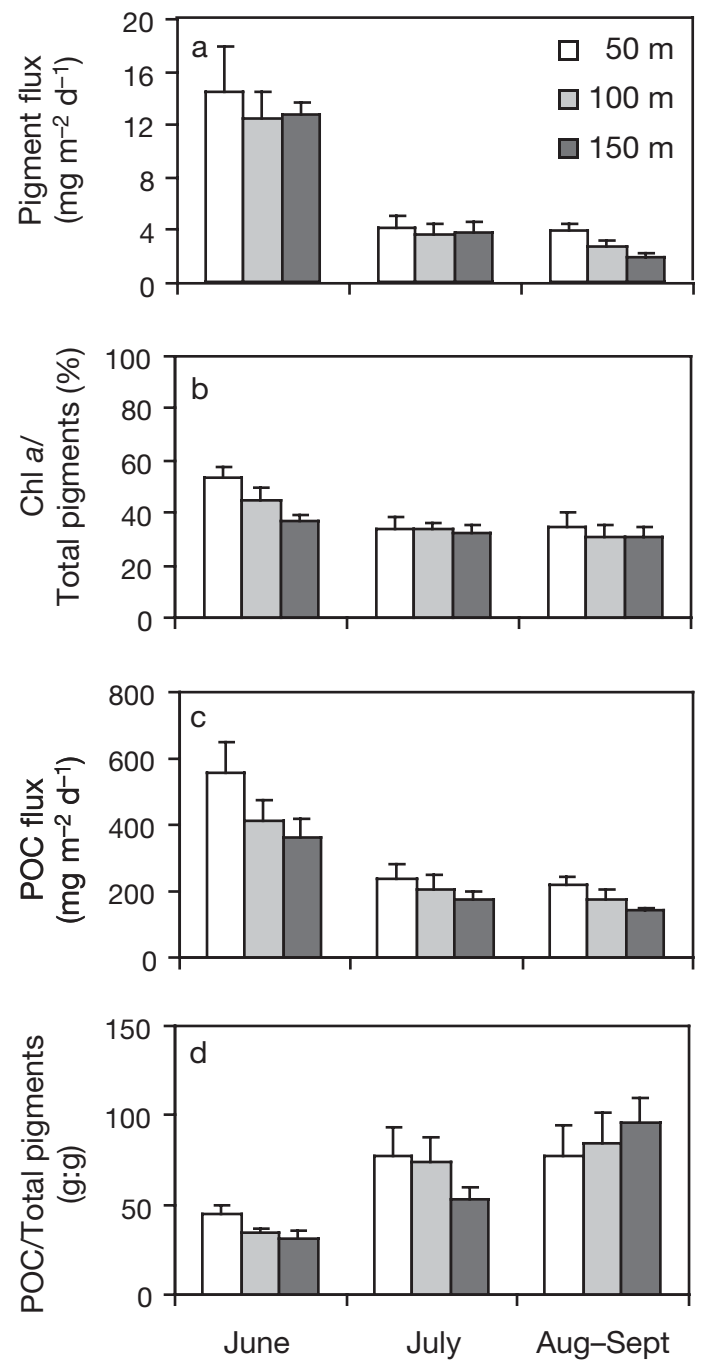

Fig. 2. Seasonal changes in (a) sedimentation rate of total pigments (chl $a+$ pheopigments), (b) percent chl $a$ in total pigments, (c) sedimentation rate of particulate organic carbon (POC) and (d) ratio of POC to total pigments, from particle interceptor traps deployed at 50,100 and $150 \mathrm{~m}$ in the North Water region. Means and standard errors are shown (number of stations visited [n]: $\mathrm{n}=11$ for June, $\mathrm{n}=8$ for July and $\mathrm{n}=12$ for August-September) numbers of enumerated cells (Smayda 1978). The number and size of fecal pellets were also determined in buffered formaldehyde subsamples using the inverted microscope. The length and width of entire and broken pellets were measured and volumes were estimated using appropriate geometric equations. The total volume of feces was estimated for each sample. Pellets were also grouped in various size-classes based on their width. Phytoplankton carbon biomass was estimated using the conversion factor of MendenDeuer \& Lessard (2000) for diatoms, while the carbon contribution of fecal pellets was estimated with the conversion factor of González \& Smetacek (1994).

Samples for suspended POC and pigments were collected at 6 to 12 depths between 0 and $150 \mathrm{~m}$ using a rosette system (General Oceanics) equipped with $10 \mathrm{l}$ water bottles (Brooke Ocean Technology). The same methods as described above were then used to determine suspended POC and pigments.

Mathematical and statistical analyses. Bulk sinking velocities $(S V)\left(\mathrm{m} \mathrm{d}^{-1}\right)$ were calculated using the following equation:

$$
S V=\frac{\text { Flux }_{z}}{\left(\int_{0}^{z} S M\right) / z}
$$

where Flux $_{z}$ is the sedimentation flux at depth $z$ $\left(\mathrm{mg} \mathrm{m}^{-2} \mathrm{~d}^{-1}\right), z$ is the sampling depth $(\mathrm{m})$, and $\int_{0}^{2} S M$ is the integrated suspended biomass $\left(\mathrm{mg} \mathrm{m}^{-2}\right)$ from surface to the particle interceptor trap depth $z$. The assumption of this equation is that all suspended biomass above the trap depth contributes to the sinking material and it does not take into account the horizontal export.

Statistical differences between average sedimentation fluxes were tested for each sampling period (temporal scale) and each depth horizon (vertical scale) using Kruskal-Wallis tests (Sokal \& Rohlf 1981). All regressions presented are reduced major axis Model II regressions, which account for the fact that both variables are subject to error due to analytical measurement (Sokal \& Rohlf 1981).

\section{RESULTS}

\section{Seasonal sedimentation patterns}

Highly significant seasonal changes in the sinking material were observed during the sampling period, as shown in Figs. 2 to 7. The total amount of pigments sinking out of the euphotic zone was highest in June at all depths (Kruskal-Wallis, p < 0.01) $(14.4,12.4$ and $12.7 \mathrm{mg}$ pigment $\mathrm{m}^{-2} \mathrm{~d}^{-1}$ at 50,100 and $150 \mathrm{~m}$, respectively; Fig. 2a). Pigment sedimentation rates decreased 


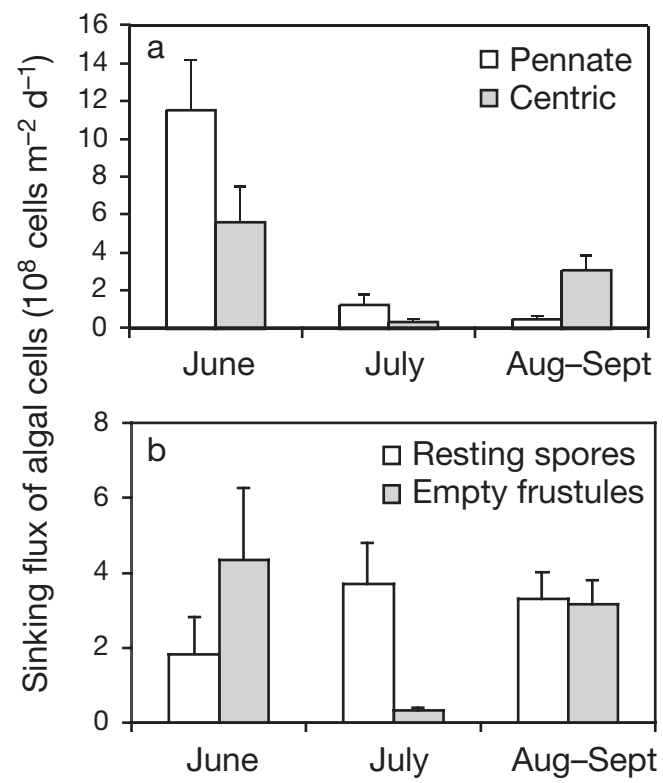

Fig. 3. Seasonal changes in the cell composition of the sinking material at $50 \mathrm{~m}$ in the North Water region: abundance of (a) pennate and centric diatoms, and (b) resting spores and empty diatom frustules. Means and standard errors are shown (number of stations visited [n]: $\mathrm{n}=11$ for June, $\mathrm{n}=8$ for July and $\mathrm{n}=12$ for August-September)

in July $\left(4.1,3.6\right.$ and $3.8 \mathrm{mg}$ pigment $\mathrm{m}^{-2} \mathrm{~d}^{-1}$ at 50, 100 and $150 \mathrm{~m}$, respectively; Fig. 2a) and remained about the same in August-September (3.9, 2.6 and $1.8 \mathrm{mg}$ pigment $\mathrm{m}^{-2} \mathrm{~d}^{-1}$ at 50, 100 and $150 \mathrm{~m}$, respectively; Fig. 2a). The average total pigment sinking fluxes were consistently higher at $50 \mathrm{~m}$ compared to the other depths, although the difference was statistically significant only for the August-September period (Kruskal-Wallis, $\mathrm{p}<0.05$ ).

The contribution of $\mathrm{chl}$ a to the total sinking pigments decreased during the sampling period (Fig. 2b). This decrease was statistically significant at 50 and $100 \mathrm{~m}$ (from an average of 53 and $45 \%$ in June to 35 and $31 \%$ in August-September at 50 and $100 \mathrm{~m}$, respectively; Kruskall-Wallis, $\mathrm{p}<0.05)$. The trend was not statistically significant at $150 \mathrm{~m}$. The proportion of chl $a$ in total pigments decreased significantly with depth only during June (from $53 \%$ at $50 \mathrm{~m}$ to $37 \%$ at $150 \mathrm{~m}$; Kruskall-Wallis, $\mathrm{p}<0.05)$.

POC sinking fluxes showed maximum values (>364 mg C m $\mathrm{m} \mathrm{d}^{-1}$ ) in June, for all depths (KruskallWallis, $\mathrm{p}<0.05$ ) (Fig. 2c). During the other months, POC sinking fluxes ranged between $142 \mathrm{mg} \mathrm{C} \mathrm{m}^{-2} \mathrm{~d}^{-1}$ (in August to September at $150 \mathrm{~m}$ ) to $240 \mathrm{mg} \mathrm{C} \mathrm{m}^{-2} \mathrm{~d}^{-1}$ (in July at $50 \mathrm{~m}$ ), with no significant seasonal trend. POC sinking fluxes decreased with depth, but this trend was statistically significant only for the August to
September period (Kruskall-Wallis, $p<0.05$ ). The POC/total pigment ratio (Fig. 2d) was lower in June than during other months at all depths, but this trend was statistically significant only at 100 and $150 \mathrm{~m}$ (Kruskall-Wallis, p < 0.01). The POC/total pigment ratio decreased with depth in June and July (not statistically significant), while there was a slight increase with depth in August-September (not statistically significant).

Strong seasonal changes were observed in the composition of the sinking diatom assemblage at $50 \mathrm{~m}$ (Fig. 3). In June and July, pennate diatoms dominated the sinking assemblage in number (range: 67 to $77 \%$ ) although the difference was only significant for the month of June (Kruskal-Wallis, p < 0.01) (Fig. 3a). Centric diatom species showed 2 peaks of sedimentation, in June and August-September. However, centric diatoms dominated the sinking diatom cell assemblage only during the August-September period, making up an average of ca. $86 \%$ of the total sinking diatom numbers.

The sedimentation rate of diatom resting spores increased from June to July and remained relatively stable thereafter, although the trend was not statistically significant (Fig. 3b). The relative contribution of resting spores to total sinking cell numbers (excluding empty frustules) was 7,66 and $46 \%$ for the sampling periods, respectively. Empty diatom frustules were abundant in June and August-September, but they were in low number in the sinking assemblage during July (Kruskall-Wallis, $\mathrm{p}<0.05$ ).

Four diatom species dominated the particle interceptor trap assemblage in the North Water region, each making up $>25 \%$ of the relative abundance during at least one of the sampling periods (Fig. 4). Two pennate species, Fragilariopsis cylindrus and Fossula arctica, and 2 centric species, Melosira arctica and Chaetoceros socialis, were dominant. Together, these 4 species rep-

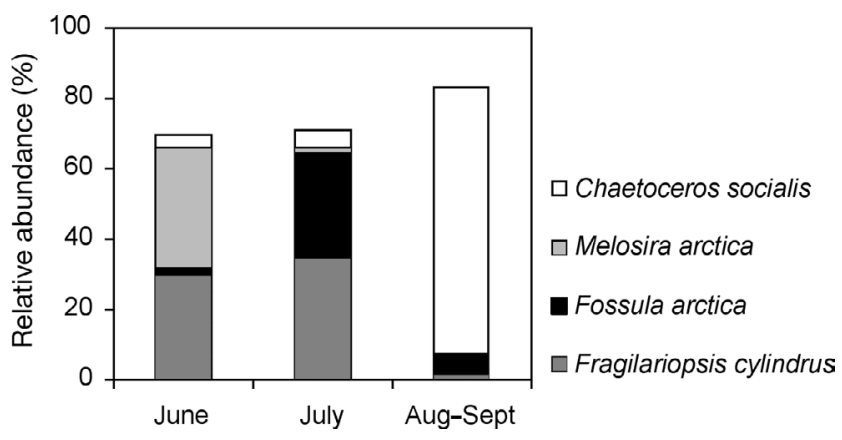

Fig. 4. Cumulative abundance of the 4 dominant diatom species ( $>25 \%$ of the relative abundance during at least 1 sampling period) in particle interceptor traps deployed at $50 \mathrm{~m}$ in the North Water region 
resented ca. 69,70 and $83 \%$ of total cell numbers in June, July and August-September, respectively. In June, $M$. arctica was the most abundant species, making up ca. $34 \%$ of total diatom numbers, a value slightly higher than the proportion of F. cylindrus (ca. $29 \%$ ). In July, F. cylindrus dominated the diatom assemblage (ca. $34 \%$ ) followed by F. arctica (ca. $30 \%$ ). The abundance of these 2 species decreased in August-September, making up only 1 and $5 \%$ of total cell numbers, respectively. At that time, C. socialis became strongly dominant, representing са. $76 \%$ of diatom numbers. The rest of the diatom assemblage was composed of a mix of pennate species in June (principally Synedropsis hyperborea, Nitzschia frigida and Thalassiotrix longissima), and by centric species in July (Thalassiosira nordenskioeldii and T. hyalina) and August-September (Chaetoceros decipiens and Attheya septentrionalis).
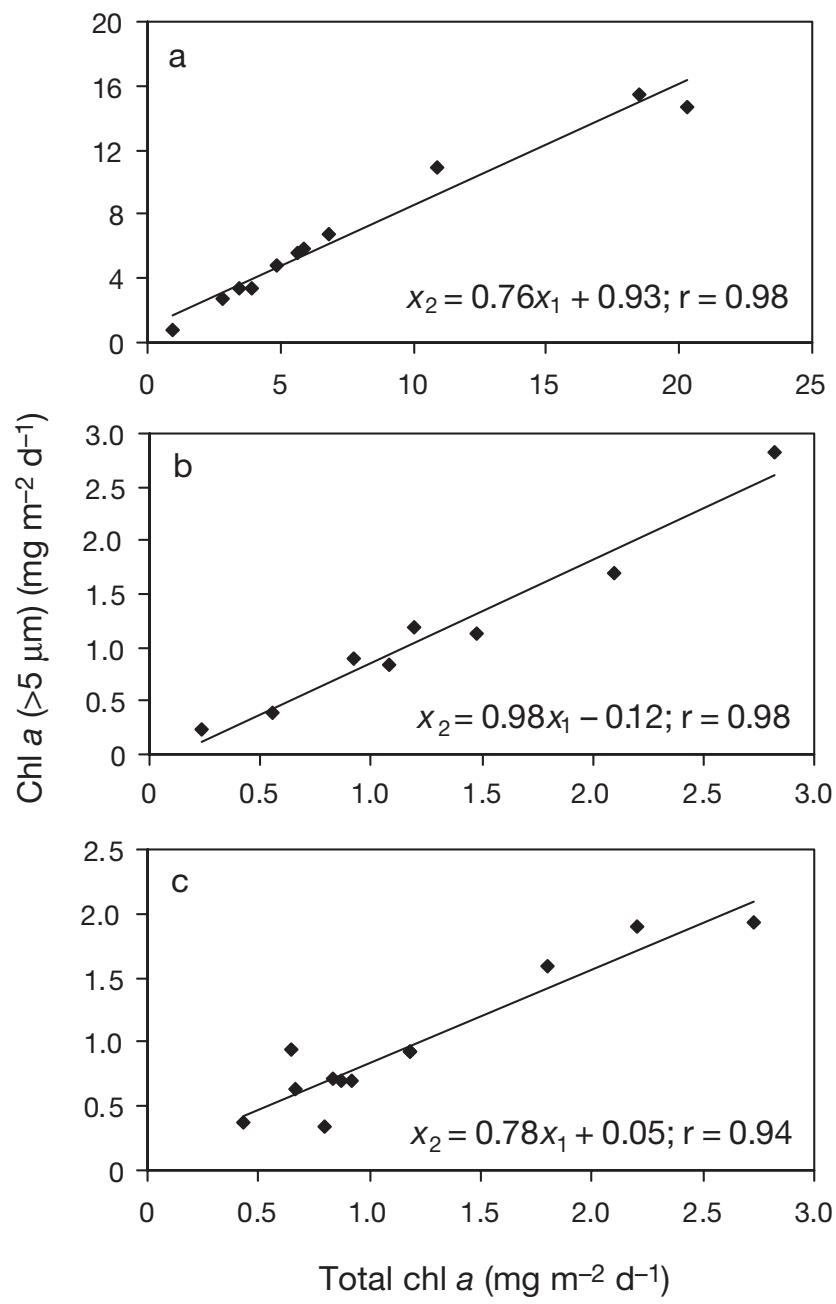

Fig. 5. Contribution of large phytoplankton cells $(>5 \mu \mathrm{m})$ to the total chl a sinking fluxes at $50 \mathrm{~m}$ in (a) June, (b) July and (c) August-September in the North Water region. Reduced major axis regressions are shown for the 3 periods
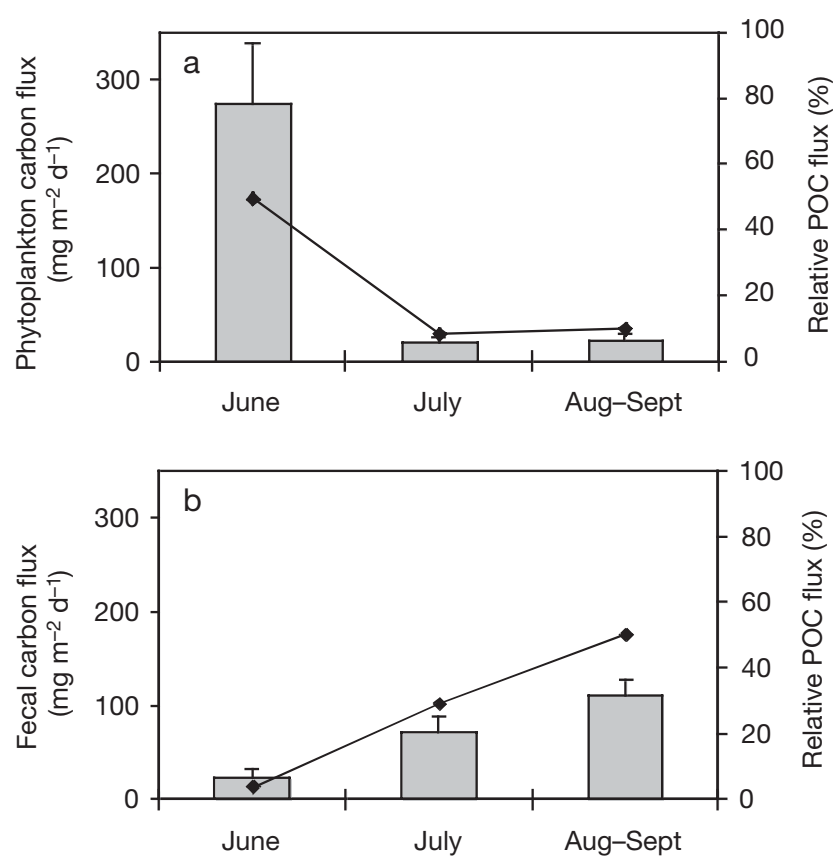

Fig. 6. Seasonal changes in sedimentation rates of (a) phytoplankton carbon biomass and (b) fecal pellet carbon from particle interceptor traps deployed at $50 \mathrm{~m}$ in the North Water region. Means and standard errors are shown. Lines represent the percent contribution of phytoplankton and fecal carbon to the total particulate organic carbon (POC) sinking flux

The contribution of large phytoplankton cells (chl a $>5 \mu \mathrm{m})$ to the total sinking fluxes of pigments at $50 \mathrm{~m}$ was estimated from regression analyses (Fig. 5). Cells larger than $5 \mu \mathrm{m}$ contributed to 76, 98 and $78 \%$ of the total pigment fluxes in June, July and August-September, respectively. All regressions are highly significant (regression coefficients of $0.98,0.98$ and 0.94 for June, July and August-September, respectively).

The carbon contribution of phytoplankton cells and fecal pellets to the sinking material $(50 \mathrm{~m})$ is shown in Fig. 6. The sinking export of carbon due to phytoplankton cells was $50 \%$ of the total POC sinking out of the euphotic zone in June (Fig. 6a). Phytoplankton carbon sedimentation rapidly decreased thereafter and remained low until the end of the sampling period (Kruskall-Wallis, $\mathrm{p}<0.01$ ), representing 8 and $10 \%$ of total sinking POC in July and in August-September, respectively. The phytoplankton C/chl a ratios (g:g) were below 50 (36, 15 and 19 for June, July and August-September, respectively), which is indicative of actively growing phytoplankton.

The carbon contribution of fecal pellets to the total POC sinking export showed an inverse pattern to that of phytoplankton carbon (Fig. 6b). Sinking export of 
fecal pellet carbon consistently increased during the sampling season (Kruskall-Wallis, $\mathrm{p}<0.05$ ), ranging from $4 \%$ in June to $50 \%$ in August-September. On average, phytoplankton and fecal pellets comprised $50 \%$ of the POC sinking export during the sampling period (range: 37 to $60 \%$ ).

The carbon contribution of fecal pellets is examined as a function of their size range in Fig. 7. All size ranges, except the 40-60 $\mu \mathrm{m}$ class, showed a significant increase in their sinking fluxes between June and August-September (Kruskall-Wallis, $p<0.05$ ). In June and July, larger pellets $(>120 \mu \mathrm{m})$ made up 60 and $44 \%$ of the total fecal pellet flux, respectively. In August-September, the 100 to $120 \mu \mathrm{m}$ class made up $38 \%$ of the total fecal pellet flux.

\section{Summary budget: Sinking export of phytoplankton biomass and production}

The sinking velocity estimates for POC and pigments (chl $a$ and pheopigments) are presented in Table 2. For POC, the estimated sinking velocities decreased considerably from June to August-September for all sampling depths (Kruskall-Wallis, $\mathrm{p}<0.05$ ). Values were at least twice as high in June as in August-September. Moreover, within a given period, the sinking velocity increased with depth, especially during June (not statistically significant). The average sinking velocity for the complete sampling period followed the same trend and increased with depth. For chl $a$, the sinking velocity showed a seasonal trend similar to that of POC (seasonal decrease) (Kruskall-Wallis, $\mathrm{p}<0.05$ ), except at $50 \mathrm{~m}$ (Table 2). At that depth, the chl a sinking velocity decreased from June to July and then increased in August-September. During most of the studied period (June, July and the average of the complete period), the sinking velocity increased with depth (Kruskall-Wallis, $\mathrm{p}<0.05$ for July only). During August-September, the highest chl a sinking velocity was found at $100 \mathrm{~m}$. The sinking velocities of pheopigments were much higher than those of POC and chl a (Table 2). They showed a seasonal decrease as did POC and chl a (not statistically significant), except at $150 \mathrm{~m}$, where the highest sinking velocity was found in July. Contrary to chl $a$, the sinking velocity of pheopigments decreased with depth during almost all the studied period (June, August-September and the average of the complete

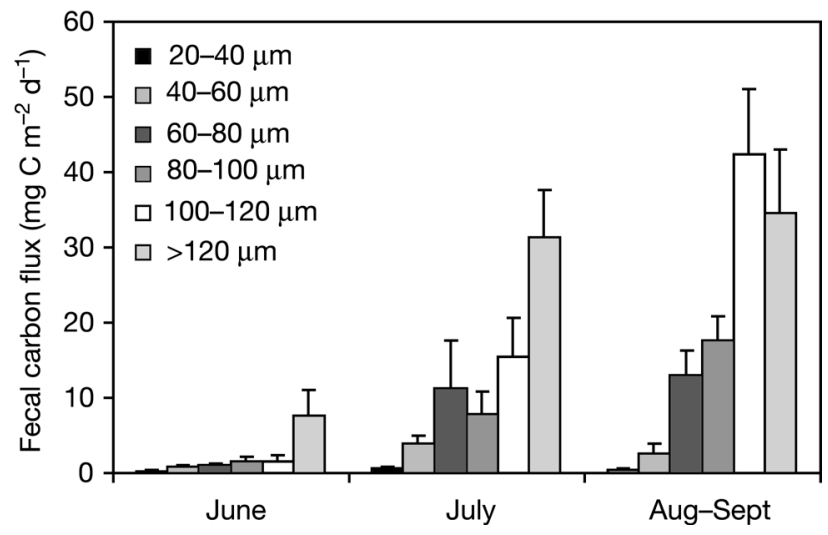

Fig. 7. Seasonal changes in sedimentation rates of fecal pellet carbon as a function of the pellet size-classes (6 classes ranging from $20-40 \mu \mathrm{m}$ to $>120 \mu \mathrm{m}$ ) in particle interceptor traps deployed at $50 \mathrm{~m}$ in the North Water region. Means and standard errors are shown

period) (not statistically significant) but mostly in June. During July, the sinking velocity increased with depth.

We estimated the percentage of particulate phytoplankton production sinking out of the euphotic zone (Table 3) using phytoplankton POC production values published in Klein et al. (2002). The highest sinking export of phytoplankton POC production occurred during July, when more than half of that production sank out of the euphotic zone (50 m) (Table 3). During the other periods, the estimated percent export ranged between ca. 32 and $39 \%$ at $50 \mathrm{~m}$. For the total sampling period, an average of ca. $35 \%$ of the phytoplankton POC production sank out of the euphotic zone and ca. $25 \%$ reached $150 \mathrm{~m}$.

Table 2. Sinking velocity $\left(\mathrm{m} \mathrm{d}^{-1}\right.$ ) of particulate organic carbon (POC), chlorophyll a (chl a) and pheopigments (pheo) at different depths and sampling periods. Averages, means and standard errors are given

\begin{tabular}{|c|c|c|c|c|}
\hline \multirow{2}{*}{ Variable } & \multirow{2}{*}{ Period } & & \multirow{2}{*}{$\begin{array}{c}\text { Depth }(\mathrm{m}) \\
100\end{array}$} & \multirow[b]{2}{*}{150} \\
\hline & & 50 & & \\
\hline \multirow[t]{4}{*}{ POC } & June & $1.83 \pm 0.29$ & $1.92 \pm 0.30$ & $2.25 \pm 0.38$ \\
\hline & July & $1.04 \pm 0.12$ & $1.31 \pm 0.18$ & $1.32 \pm 0.14$ \\
\hline & August-September & $0.90 \pm 0.12$ & $0.93 \pm 0.12$ & $0.96 \pm 0.09$ \\
\hline & Average & 1.25 & 1.37 & 1.52 \\
\hline \multirow[t]{4}{*}{$\operatorname{chl} a$} & June & $1.71 \pm 0.38$ & $2.13 \pm 0.56$ & $3.52 \pm 1.41$ \\
\hline & July & $0.64 \pm 0.10$ & $0.93 \pm 0.19$ & $1.26 \pm 0.19$ \\
\hline & August-September & $0.82 \pm 0.10$ & $0.90 \pm 0.17$ & $0.85 \pm 0.11$ \\
\hline & Average & 1.09 & 1.34 & 1.87 \\
\hline \multirow[t]{4}{*}{ pheo } & June & $13.06 \pm 5.19$ & $8.54 \pm 5.81$ & $3.37 \pm 16.36$ \\
\hline & July & $6.33 \pm 1.10$ & $7.29 \pm 1.52$ & $9.52 \pm 2.07$ \\
\hline & August-September & $6.99 \pm 0.95$ & $6.91 \pm 1.70$ & $5.87 \pm 1.24$ \\
\hline & Average & 8.09 & 7.58 & 6.25 \\
\hline
\end{tabular}


Table 3. Percentage of the daily phytoplankton particulate production in the euphotic zone sinking to different depths. Phytoplankton production estimates are from Klein et al. (2002). Monthly and seasonal averages are shown

\begin{tabular}{|lcccc|}
\hline Period & $\begin{array}{c}\text { Average } \\
\text { particulate } \\
\text { phytoplankton } \\
\text { production } \\
\left.\text { (mg C m }{ }^{-2} \mathrm{~d}^{-1}\right)\end{array}$ & \multicolumn{4}{c|}{$\begin{array}{c}\text { Particulate } \\
\text { phytoplankton } \\
\text { production exported } \\
\text { through sinking (\%) }\end{array}$} \\
\hline June & 1709 & $50 \mathrm{~m}$ & $100 \mathrm{~m}$ & $150 \mathrm{~m}$ \\
July & 414 & 32.4 & 24.0 & 21.3 \\
$\begin{array}{l}\text { August- } \\
\text { September } \\
\text { Average }\end{array}$ & 565 & 58.0 & 50.5 & 42.4 \\
& 896 & 38.8 & 31.3 & 25.2 \\
\hline
\end{tabular}

\section{DISCUSSION}

\section{Seasonal sedimentation patterns}

A coverage of seasonal sedimentation in the NOW over the whole productive summer period, from June to September, was obtained by combining extensive sampling with short-term particle interceptor traps from the 1998 (June and July) and 1999 (AugustSeptember) expeditions. The NOW polynya presents some recurrent physical and biological features, such as the position of its northern limit (Dunbar 1969) and the timing of the spring phytoplankton bloom (Booth et al. 2002). These recurring patterns suggest that it is appropriate to combine and analyze results from successive years to obtain a complete seasonal cycle. Indeed, some studies from the NOW have used this approach to develop complete seasonal patterns of biogeochemical features (e.g. Booth et al. 2002, Klein et al. 2002, Miller et al. 2002). Inter-annual variability in the size and amplitude of the bloom was observed in late spring of 1998 and 1999 (Bélanger 2001). However, the variability in late summer-early autumn was relatively small for the $2 \mathrm{yr}$ studied. Consequently, it appears appropriate to combine both years to obtain a complete seasonal pattern. As in June and July (Michel et al. 2002), there was no definite spatial sedimentation pattern during August-September in the NOW.

At all stations, the particle interceptor traps were located below the euphotic zone $(1 \%$ of the surface light) (except for Stn C2, where the depth of the euphotic zone was $75 \mathrm{~m}$, and Stn D1 in June, where it was $50 \mathrm{~m}$ ) and below the surface mixed layer (see Table 2 in Booth et al. 2002). Therefore, the observed fluxes represent the material exported out of the euphotic zone. Although we could not directly estimate the trapping efficiency of the particle interceptor traps during this study, their aspect ratio points to effective trapping efficiency for free-drifting sediment traps (e.g. Blomqvist \& Håkanson 1981, Butman 1986, Baker et al. 1988). Accordingly, POC fluxes obtained from our free-drifting trap deployments were in close agreement with flux estimates from water column ${ }^{234} \mathrm{Th}$ deficits and $\mathrm{POC} /{ }^{234} \mathrm{Th}$ ratios in sinking particles (Amiel et al. 2002). In July, POC flux estimates from ${ }^{234} \mathrm{Th}$ were $329 \pm 161 \mathrm{mg} \mathrm{C} \mathrm{m}^{-2} \mathrm{~d}^{-1}$ (Amiel et al. 2002), whereas POC fluxes from drifting sediment traps at 50 $\mathrm{m}$ (this study) were $256 \pm 126 \mathrm{mg} \mathrm{C} \mathrm{m}^{-2} \mathrm{~d}^{-1}$. New production estimates and comparison with dissolved inorganic carbon disappearance rate during the months of April to June also reveals that the missing carbon was balanced with carbon fluxes measured from the freedrifting traps (Michel et al. 2002, Tremblay et al. 2002a).

In the NOW, the maximum sedimentation of organic matter occurred in June and was followed by a rapid decrease in July (Figs. 2 \& 3; see also Hargrave et al. 2002, Michel et al. 2002, Sampei et al. 2002). This decrease continued in August-September for pigments, POC (Fig. 2a-c), and phytoplankton cells (Fig. 3a). The sedimentation peak in June can be attributed to a mismatch between phytoplankton production and zooplankton grazing. Recycling of matter, by zooplankton or microbial activities, took place later in the season, as reflected by the decrease in sinking fluxes (Fig. 2a,c), the increase of pheopigments (Fig. 2b) and the increase of the ratio of POC to total pigments (Fig. 2d) in the sinking material. The strong sedimentation episode in June followed the early phytoplankton bloom in the polynya, which took place in May or June, depending on the region observed (Klein et al. 2002). Termination of this bloom was likely due to nitrogen limitation (Tremblay et al. 2002b).

The sinking export of organic carbon of the NOW polynya is earlier and higher compared to the Northeast Water polynya (NEW; off northeast Greenland) (Bauerfeind et al. 1997). Sinking fluxes of POC in the NOW are also higher than those of the Ross Sea polynya (Antarctic) (Asper \& Smith 1999, Gowing et al. 2001). The higher sinking fluxes observed in the NOW can be explained by the higher primary production in that polynya (depth-integrated average of 550 to $2468 \mathrm{mg} \mathrm{C} \mathrm{m}^{-2} \mathrm{~d}^{-1}$ in September and June, respectively; Klein et al. 2002) compared to primary production rates in the Ross Sea polynya (depth-integrated rate between 336 and $1680 \mathrm{mg} \mathrm{C} \mathrm{m}^{-2} \mathrm{~d}^{-1}$ during the austral summer; Bender et al. 2000). Furthermore, the sedimentation fluxes appeared to be more constant during the productive period in the Ross Sea polynya (Asper \& Smith 1999, Gowing et al. 2001) compared to the NOW (Michel et al. 2002, present study). This low versus high variability in the sedimentation of organic material during the season is likely related to patterns 
of production that appear to be less variable in the Ross Sea polynya (Bender et al. 2000) compared to the NOW (Klein et al. 2002).

Sedimentation in the NOW presents similarities with adjacent areas of the Arctic. For example, the average POC flux during the productive period in Frobisher Bay (311 mg C m $\mathrm{m}^{-2} \mathrm{~d}^{-1}$ at $33 \mathrm{~m}$; Atkinson \& Wacasey 1987) and the range of vertical POC fluxes during the summer in the central Barents Sea (150 to $300 \mathrm{mg} \mathrm{C} \mathrm{m} \mathrm{C}^{-1}$ between 30 and $200 \mathrm{~m}$; Wassmann 1989, Wassmann et al. 1990, Olli et al. 2002) are comparable to the average POC fluxes observed in the NOW during our sampling period (from 228 to $338 \mathrm{mg} \mathrm{C} \mathrm{m}^{-2} \mathrm{~d}^{-1}$ at 150 and $50 \mathrm{~m}$, respectively). However, the maximum sedimentation takes place earlier in the central Barents Sea (in May; Olli et al. 2002) and later in Frobisher Bay (in August; Atkinson \& Wacasey 1987) compared to the NOW (in June; Figs. 2 \& 3), following the phytoplankton bloom in each region (beginning of May in the Barents Sea, Reigstad et al. 2002; July in the Frobisher Bay, Hsiao 1988; end of May to beginning of June in the NOW, Klein et al. 2002).

The species composition in the trap assemblage also showed strong seasonal variations in the NOW (Fig. 4). In June, there was a dominance of pennate diatoms (Fig. 3a), mainly Fragilariopsis cylindrus, although Melosira arctica, a centric diatom, was the single most abundant diatom species (Fig. 4). This reflected the phytoplankton composition observed in the polynya during early summer (Lovejoy et al. 2002). Pennate diatoms are better adapted to early season conditions since they can grow better under lower light intensities than centric diatoms (Hsiao 1992). A dominance of pennate diatoms, mainly Fossula arctica, in the total cell flux was also observed in July (Fig. 4). During August-September, the increase in centric diatom sedimentation (Fig. 3a) was mainly due to Chaetoceros socialis (Fig. 4). A succession pattern from pennate (Achnanthes sp. and Fragilaria sp.) to centric (Chaetoceros spp.) diatoms was described for water column assemblages near Igloolik Island (Eastern Canadian Arctic) more than $40 \mathrm{yr}$ ago (Bursa 1961). More recently, a similar succession between pennate (Achnanthes sp. and Nitzschia spp.) and centric (Chaetoceros sp.) diatoms has been reported for the ice algae and phytoplankton communities in Frobisher Bay (Hsiao 1992). The fact that a similar succession of species was observed in the particle interceptor trap assemblage in the NOW reflects that the polynya behaves in a way similar to adjacent Arctic areas, although maximum production and sedimentation periods occur much earlier.

The rapid increase in sinking cell numbers at the end of the sampling season indicates an autumn bloom, which is characteristic of the boreal zone (Wassmann et al. 1990, 1991). The important sedimentation of resting spores over all the sampling periods (Fig. 3b), mainly from Chaetoceros socialis, also supports the hypothesis that these spores can act as a seed population for a late phytoplankton bloom, as suggested by Michel et al. (2002). Indeed, an increased abundance of C. socialis was observed in the water column over the whole polynya in July and August-September (Mostajir et al. 2001, Booth et al. 2002) and in the particle interceptor traps during late summer-early autumn (Fig. 4). This species may enter a resting stage for wintering (Garrison 1984), as a result of the nutrient limitation observed in the NOW (Tremblay et al. $2002 b)$, and then potentially contribute to next year's bloom. However, C. socialis did not contribute to the phytoplankton bloom in the spring and was abundant only later in the season (Booth et al. 2002, Lovejoy et al. 2002). As observed in the NOW water column by Booth et al. (2002) and in the particle interceptor trap samples in Auke Bay (Alaska) by Waite et al. (1992a) (and see 'Results' section), C. socialis (5 to $14 \mu \mathrm{m}$ ) appeared after the bloom of a larger centric diatom cell, Thalassiosira spp. (5 to $66 \mu \mathrm{m})$, which is more tolerant of lower temperatures (Waite et al. 1992a,b).

In general, it is considered that a single summer bloom occurs in polar regions (Wassmann et al. 1990, 1991). Peak sedimentation is generally observed during summer, after the spring bloom, while little sedimentation takes place during the spring. This typical sedimentation pattern corresponds to the seasonal pattern observed in the NOW. However, the sedimentation pattern in the NOW also has similarities with boreal regions (Wassmann et al. 1990, 1991). In these regions, 2 episodes of maximum sedimentation are generally observed, one during late spring and one in early autumn. The peak sedimentation in early autumn in the NOW is not as strong as that in June, but there was a large increase in the sedimentation of centric diatoms and fecal pellets in August-September (Figs. 3a \& 6). This indicates that the NOW, even though it is a polar region, also behaves like a boreal zone, with 2 episodes of sedimentation, one following the spring bloom and one later in the season.

\section{Composition of the exported matter}

About $50 \%$ of the vertical POC flux in the NOW (54, 38 and $61 \%$ in June, July and August-September, respectively; Fig. 6) was composed of both diatom cells and fecal pellets. In contrast, during the periods of the highest flux rates (June and August-September) in the NEW, diatoms and fecal pellets made up an average of only ca. 27 and $11 \%$ of the total POC flux, respectively 
(Bauerfeind et al. 1997). The total POC flux in the NEW, however, may have been underestimated because of partial solubilization of POC into dissolved organic carbon in the multi-cupped sediment traps (Kähler \& Bauerfeind 2001). Clearly, both the magnitude and the relative values of the fecal pellet and phytoplankton carbon fluxes were much higher in the NOW compared to the NEW polynya (173.4 $\mathrm{mg} \mathrm{C} \mathrm{m}^{-2} \mathrm{~d}^{-1}$ on average at $50 \mathrm{~m}$ in the NOW versus less than $6.2 \mathrm{mg} \mathrm{C} \mathrm{m}^{-2} \mathrm{~d}^{-1}$ at $130 \mathrm{~m}$ in the NEW; Bauerfeind et al. 1997).

In the NOW, intact phytoplankton cells made up a large proportion of the carbon sinking flux in June, after the spring phytoplankton bloom, contributing half $(50 \%)$ of the POC exported during that month (Fig. 6a). This value is comparable with values from the Barents Sea, where phytoplankton carbon makes up $50 \%$ of the total sinking POC between 30 and $200 \mathrm{~m}$ during the spring after the phytoplanktonic bloom (Olli et al. 2002). However, this is a low value compared to the NEW polynya, where diatoms contribute up to $81 \%$ of the total POC flux at the time of the ice melt in June (Bauerfeind et al. 1997). The diatom cells exported in the NOW were mostly large cells, as shown by the high contribution of chl $a$ in cells $>5 \mu \mathrm{m}$ (Fig. 5), especially in July, when a large centric diatom species, Thalassiosira spp., was the most abundant sinking algal species.

Zooplankton grazers (mainly the copepod Calanus spp.; Ringuette et al. 2002) also appeared to play a key role in the transfer of organic carbon in the polynya, as shown by the high production (Sampei et al. 2002) and sedimentation (Fig. 6) of fecal pellets at the end of summer-beginning of autumn. Over all the sampling period, fecal pellets made up about 5 to $50 \%$ (average of $28 \%$ ) of the POC sinking out of the euphotic zone (Fig. 6b). Similar fecal pellet contributions (19 to 32\%) were reported in the NEW during August-September by Bauerfeind et al. (1997). The ingestion rate of copepods varied greatly in the NOW, from 1.03 to

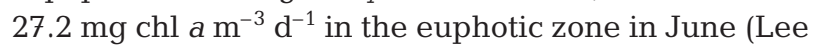
et al. 2003), indicating that copepod grazing had a significant impact on phytoplankton biomass. In comparison, the estimated median ingestion rate of appendicularians was $0.01 \mathrm{mg} \mathrm{chl} \mathrm{a} \mathrm{m}{ }^{-3} \mathrm{~d}^{-1}$ in the upper $50 \mathrm{~m}$ in June and July (Acuña et al. 2002), which could be considered as a moderate daily impact. Large fecal pellets $(>120 \mu \mathrm{m})$ always contributed over $31 \%$ of the total pellet flux in the NOW (Fig. 7). These large feces likely came from macrozooplankton such as Euphausiids (Romero et al. 2000). This might indicate that the large zooplankton community played a crucial role in the carbon fluxes during the productive season.

Empty diatom frustules were also observed in the sinking material, especially during June and August-September (Fig. 3b). Even though the range of variation in the sedimentation fluxes of empty frustules was large, a dominance of pennate diatom frustules was observed in July while empty centric frustules dominated in August-September (data not shown), so it reflected the composition of the bloom. At the end of the productive period, the flux of algal cells was mainly composed of empty frustules of centric diatoms and resting spores. Overall, the sinking export of empty frustules and spores would not contribute much to the downward export of organic carbon. However, it certainly contributed to channeling biogenic silica to deeper waters (see Michel et al. 2002).

\section{Sinking export of phytoplankton biomass and production}

The NOW shows an extensive period of primary production, lasting up to 6 months (Booth et al. 2002, Klein et al. 2002, Mei et al. 2002, Tremblay et al. 2002a). By its high export fluxes of material (Hargrave et al. 2002, Michel et al. 2002, Sampei et al. 2002, and this paper), the NOW polynya appears to be an exceptional site in the high Arctic with regard to the transfer of organic matter towards benthic consumers and, eventually, towards its sequestration in the sea floor. During June, Sampei et al. (2002) estimated a flux of $81 \mathrm{mg} \mathrm{C} \mathrm{m}^{-2} \mathrm{~d}^{-1}$ at $50 \mathrm{~m}$ above the bottom (using the equation of Martin et al. 1987), which represented about $12 \%$ of the material exported out of the euphotic zone. Hamel et al. (2002) estimated that the burial flux of organic carbon in the southeastern part of the NOW region represents 4 to $6 \%$ of the annual primary production in the euphotic zone. In addition, the high primary production provides abundant food resources to the pelagic food web, as reflected by the high fecal pellet fluxes exported out of the euphotic zone over the whole sampling season.

The bulk sinking velocities of POC and chl a estimated for the NOW were relatively low, $<3 \mathrm{~m} \mathrm{~d}^{-1}$ (except at $150 \mathrm{~m}$ in June for chl $a_{\text {; }}$ Table 2). The latter values are higher than estimates from settling column experiments ( 0.1 to $0.7 \mathrm{~m} \mathrm{~d}^{-1}$ between April and July; Mei et al. 2003). This discrepancy can be attributed to differences in the physiological conditions of the cells in settling column experiments compared to those collected in particle interceptor traps. The settling column experiments were performed on suspended chl a biomass collected at depths of 50 and $1 \%$ of the surface irradiance (Mei et al. 2003), thus on cells which are likely to be in good physiological condition. Mei et al. (2003) proposed that the abundant supply of nutrients and the $24 \mathrm{~h}$ of daylight might have caused the low sinking velocities observed during their study. In contrast, the particle interceptor traps are likely to collect 
phytoplankton cells which are in poor physiological condition and have higher sinking rates. Nevertheless, our values are at the low end of the range of values reported by Smayda $(1970,1971)$, who measured velocities between 0 and $30 \mathrm{~m} \mathrm{~d}^{-1}$ for living phytoplankton. The low sinking velocities imply that particles have a long residence time in the euphotic zone and, consequently, there is ample time for efficient grazing and mineralization of the organic matter. As previously mentioned, it was shown that copepod grazing had a significant impact on the phytoplankton community (Lee et al. 2003). In turn, this affected the composition of the sinking material, as reflected by the seasonal decrease of the chl a/total pigments ratio (Fig. 2b). The observation by Huston \& Deming (2002) of an increase in bacterial abundance between May and July at the depth of the chl a maximum agrees with a long residence time and recycling of organic matter within the surface layer. The variations observed in the sinking velocities of pheopigments, especially during June and July (Table 2), point to a dissolution of the fecal matter during sinking, which might be attributed to the action of bacteria on broken feces (e.g. coprochaly).

Over the whole sampling period in the NOW, $35 \%$ of the phytoplankton production was exported by sinking, while $65 \%$ was recycled or remained suspended in the euphotic zone. This export value is higher than the one based on phytoplankton size fractions between April and July (average of $20 \%$ of the phytoplankton production; Mei et al. 2003). According to our results, Melosira arctica, a centric diatom that can grow suspended at the ice-water interface of pack ice, appears to be important in the ecosystem in June, but the sampling design did not allow for a quantitative assessment of its biomass and production. Consequently, primary production estimates for the NOW are probably underestimates. This provides a likely explanation for our higher estimate of phytoplankton production export from the euphotic zone. The different sampling periods could also explain our higher estimate, since POC sinking export was higher in August-September (Fig. 2c) than in April-May (Michel et al. 2002). In fact, if we take into consideration the entire productive period, from April to September (using values from Michel et al. 2002 for April-May), the percentage of particulate phytoplankton production in the euphotic zone exported through sinking is ca. $20 \%$. This estimate is also equivalent to the one based on the nutrient budget in the upper $150 \mathrm{~m}$ of the water column (ca. $20 \%$; Tremblay et al. 2002a). All these results confirm that the POC produced in the surface waters of the NOW is mainly transferred to the herbivorous food web even if a significant portion of that POC is exported to the benthic community.

\section{Conclusions}

In conclusion, the seasonal sedimentation pattern in the NOW area appears to be similar to that of a boreal ecosystem, with bimodal peaks of sedimentation, rather than of a typical polar ecosystem, where a single summer bloom is followed by 1 sedimentation episode (Wassmann et al. 1990, 1991). The export of POC, elevated during the spring and early summer (April to July) as shown by Michel et al. (2002), continues to be important during the end of summer-beginning of the autumn (August-September), while the sedimentation of intact phytoplankton cells and feces varied during the productive period. Finally, because of the low sinking velocities, POC produced in the surface water of the NOW is principally available for transfer to the herbivorous pelagic food web rather than export to the benthic community. Still, our budget estimates reveal that, on average, $35 \%$ of the particulate primary production sank below the euphotic zone and that $25 \%$ reached the depth of $150 \mathrm{~m}$. Our results support the hypothesis that the NOW polynya is an important Arctic area for the transfer of carbon to the herbivorous food web (Mei et al. 2003). This conclusion agrees with the abundance of higher trophic level organisms observed in the NOW polynya, including fish, mammals and birds (Stirling 1997, Acuña et al. 2002, Karnovsky \& Hunt 2002, Ringuette et al. 2002). To our knowledge, the sedimentation pattern presented in this study, obtained with free-drifting particle interceptor traps, is the first to cover almost all the productive period in an Arctic region.

Acknowledgements. This project was supported by a Research Network grant and by an individual research grant from the Natural Sciences and Engineering Research Council (NSERC) of Canada to M.G., and by financial support from the Freshwater Institute (Fisheries and Oceans Canada) to C.M. G.C. received post-graduate scholarships from NSERC, the Fondation de l'UQAR (bourse EstelleLaberge) and the Institut des sciences de la mer de Rimouski (ISMER), and financial support from Indian and Northern Affairs Canada for fieldwork. The authors gratefully acknowledge the Canadian Coast Guard officers and crew of the CCGS 'Pierre Radisson' for their invaluable support during the expedition. We also acknowledge the skilful support of the Polar Continental Shelf Project. We are especially indebted to M. Gagnon, C. Lalande, J. Deming, M.-Ė. Garneau and S. Pesant for technical assistance in the field. We also thank J.-Y. Anctil, B. LeBlanc and A. Gagné for logistical assistance; D. Bérubé for CHN analyses; M. Simard for phytoplankton identification; and W.G. Harrison, S. Roy and L. Devine for useful comments on the manuscript. I. Walsh kindly provided the drifting trap cylinders. This is a contribution to the research programs of the International North Water Polynya Study, the Freshwater Institute (Fisheries and Oceans Canada) and ISMER. 


\section{LITERATURE CITED}

Acuña JL, Deibel D, Saunders PA, Booth B, Hatfield E, Klein B, Mei Z-P, Rivkin R (2002) Phytoplankton ingestion by appendicularians in the North Water. Deep-Sea Res II 49: 5101-5115

Amiel D, Cochran JK, Hirschberg DJ (2002) ${ }^{234} \mathrm{Th} /{ }^{238} \mathrm{U}$ disequilibrium as an indicator for the seasonal export flux of particulate organic carbon in the North Water. Deep Sea Res II 49:5191-5209

Asper VL, Smith WO Jr (1999) Particle fluxes during austral spring and summer in the southern Ross Sea, Antarctica. J Geophys Res 104:5345-5359

Atkinson EG, Wacasey JW (1987) Sedimentation in Arctic Canada: particulate organic carbon flux to a shallow marine benthic community in Frobisher Bay. Polar Biol 8: $3-7$

Baker ET, Milburn HB, Tennant DA (1988) Field assessment of sediment trap efficiency under varying flow conditions. J Mar Res 46:573-592

Barber DG, Hanesiak JM, Chan W, Piwowar J (2001) Sea ice and meteorological conditions in Northern Baffin Bay and the North Water Polynya between 1979 and 1996. AtmosOcean 39:343-359

Bauerfeind E, Garrity C, Krumbholz M, Ramseier RO, Voß M (1997) Seasonal variability of sediment trap collections in the Northeast Water Polynya. Part 2. Biochemical and microscopic composition of sedimenting matter. J Mar Syst 10:371-389

Bélanger S (2001) Analyse spatio-temporelle des patrons de chlorophylle dans la polynie NOW par télédétection du capteur SeaWiFS. Masters thesis, Université de Sherbrooke

Bender ML, Dickson ML, Orchardo J (2000) Net and gross production in the Ross Sea as determined by incubation experiments and dissolved $\mathrm{O}_{2}$ studies. Deep-Sea Res II 47: 3141-3158

Blomqvist S, Håkanson L (1981) A review on sediment traps in aquatic environments. Arch Hydrobiol 91:101-132

Booth BC, Larouche P, Bélanger S, Klein B, Amiel D, Mei ZP (2002) Dynamics of Chaetoceros socialis blooms in the North Water. Deep-Sea Res II 49:5003-5025

Brown RGB, Nettleship DN (1981) The biological significance of polynyas to Arctic colonial birds. In: Stirling I Cleator H (eds) Polynyas in the Canadian Arctic. Can Wildl Serv Occas Pap 45, Canadian Wildlife Service, Ottawa, p 59-70

Bursa AS (1961) The annual oceanographic cycle at Igloolik in the Canadian Arctic, II. The phytoplankton. J Fish Res Bd Can 18:563-613

Butman CA (1986) Sediment trap biases in turbulent flows: Results from a laboratory fume study. J Mar Res 44: 645-693

Dunbar IM (1969) The geographical position of the North Water. Arctic 22:438-441

Flato GM, Boer GJ, Lee WG, McFarlane NA, Ramsden D, Reader MC, Weaver AJ (2000) The Canadian Centre for Climate Modelling and Analysis global coupled model and its climate. Clim Dyn 16:451-467

Gardner WD (2000) Sediment trap sampling in surface waters. In: Hanson RB, Ducklow HW, Field JG (eds) The changing ocean carbon cycle: a midterm synthesis of the Joint Global Ocean Flux Study. Cambridge University Press, Cambridge, p 240-181

Garrison DL (1984) Planktonic diatoms. In: Steidinger KA, Walker LM (eds) Marine plankton life cycle strategies. CRC Press, Boca Raton, FL, p 1-17
González HE, Smetacek V (1994) The possible role of the cyclopoid copepod Oithona in retarding vertical flux of zooplankton faecal material. Mar Ecol Prog Ser 113: 233-246

Gowing MM, Garrison DL, Kunze HB, Winchell CJ (2001) Biological components of Ross Sea short-term particle fluxes in the austral summer of 1995-1996. Deep-Sea Res I 48:2645-2671

Hamel D, de Vernal A, Gosselin M, Hillaire-Marcel C (2002) Organic-walled microfossils and geochemical tracers: sedimentary indicators of productivity changes in the North Water and northern Baffin Bay during the last centuries. Deep-Sea Res II 49:5277-5295

Hargrave BT, Walsh ID, Murray DW (2002) Seasonal and spatial patterns in mass and organic matter sedimentation in the North Water. Deep-Sea Res II 49:5227-5244

Hsiao SIC (1988) Spatial and seasonal variations in primary production of sea ice microalgae and phytoplankton in Frobisher Bay, Arctic Canada. Mar Ecol Prog Ser 44: 275-285

Hsiao SIC (1992) Dynamics of ice algae and phytoplankton in Frobisher Bay. Polar Biol 12:645-651

Huston AL, Deming JW (2002) Relationships between microbial extracellular enzymatic activity and suspended and sinking particulate organic matter: seasonal transformations in the North Water. Deep-Sea Res II 49:5211-5225

IPCC (Intergovernmental Panel on Climate Change) (2001) Climate change 2001; synthesis report: contribution of Working Groups I, II and III to the third assessment report of the Intergovernmental Panel on Climate Change. Cambridge University Press, Cambridge

JGOFS (Joint Global Ocean Flux Study) (1996) Protocols for the Joint Global Ocean Flux Study (JGOFS) core measurements, report No. 19. Scientific Committee on Oceanic Research, International Council of Scientific Union, Bergen

Kähler P, Bauerfeind E (2001) Organic particles in a shallow sediment trap: substantial loss to the dissolved phase. Limnol Oceanogr 46:719-723

Kamenkovich IV, Sokolov AP, Stone PH (2002) An efficient climate model with a 3D ocean and statistical-dynamical atmosphere. Clim Dyn 19:585-598

Karnovsky N, Hunt G Jr (2002) Estimation of carbon flux to dovekies (Alle alle) in the North Water. Deep-Sea Res II 49:5117-5130

Klein B, LeBlanc B, Mei ZP, Beret R and 12 others (2002) Phytoplankton biomass, production and potential export in the North Water. Deep-Sea Res II 49:4983-5002

Lee PA, Saunders PA, de Mora SJ, Deibel D, Levasseur M (2003) Influence of copepod grazing on concentrations of dissolved dimethylsulfoxide and related sulfur compounds in the North Water, northern Baffin Bay. Mar Ecol Prog Ser 255:235-248

Legendre L (1990) The significance of microalgal blooms for fisheries and for the export of particulate organic carbon in oceans. J Plankton Res 12:681-699

Legendre L, Le Fèvre J (1991) From individual plankton cells to pelagic marine ecosystems and to global biogeochemical cycles. In: Demers S (ed) Particle analysis in oceanography. Springer-Verlag, Berlin, p 261-300

Lovejoy C, Legendre L, Martineau MJ, Bâcle J, von Quillfeldt CH (2002) Distribution of phytoplankton and other protists in the North Water. Deep-Sea Res II 49:5027-5047

Lund JWG, Kipling C, Le Cren ED (1958) The inverted microscope method of estimating algal numbers and the statistical analysis of estimations by counting. Hydrobiologia 11: $143-170$ 
Martin JH, Knauer GA, Karl DM, Broenkow WW (1987) VERTEX: carbon cycling in the northeast Pacific. Deep-Sea Res 34:267-285

Mei ZP, Legendre L, Gratton Y, Tremblay JÉ, LeBlanc B, Klein B, Gosselin M (2003) Phytoplankton production in the North Water Polynya: size-fractions and carbon fluxes, April-July 1998. Mar Ecol Prog Ser 256:13-27

Mei ZP, Legendre L, Gratton Y, Tremblay JÉ and 8 others (2002) Physical control of spring-summer phytoplankton dynamics in the North Water, April-July 1998. Deep-Sea Res II 49:4959-4982

Menden-Deuer S, Lessard EJ (2000) Carbon to volume relationships for dinoflagellates, diatoms, and other protist plankton. Limnol Oceanogr 45:569-579

Michel C, Gosselin M, Nozais C (2002) Preferential sinking export of biogenic silica during the spring-summer in the North Water Polynya (northern Baffin Bay): temperature or biological control? J Geophys Res 107:10.1029/ 2000JC000408

Miller LA, Yager PL, Erickson KA, Amiel D and 8 others (2002) Carbon distributions and fluxes in the North Water, northern Baffin Bay, 1998 and 1999. Deep-Sea Res II 49: 5151-5170

Mostajir B, Gosselin M, Gratton Y, Booth B and 5 others (2001) Surface water distribution of pico- and nanophytoplankton in relation to two distinctive water masses in the North Water, northern Baffin Bay, during fall. Aquat Microb Ecol 23:205-212

Olli K, Riser CW, Wassmann P, Ratkova T, Arashkevich E, Pasternak A (2002) Seasonal variation in vertical flux of biogenic matter in the marginal ice zone and the central Barents Sea. J Mar Syst 38:189-204

Parsons TR, Maita Y, Lalli CM (1984) A manual of chemical and biological methods for seawater analysis. Pergamon Press, Toronto

Peinert R, von Bodungen B, Smetacek VS (1989) Food web structure and loss rate. In: Berger $\mathrm{WH}$, Smetacek VS, Wefer G (eds) Productivity of the ocean: present and past. John Wiley \& Sons, New York, p 35-48

Pilskaln CH, Honjo S (1987) The fecal pellets fraction of biogeochemical particle fluxes to the deep sea. Global Biogeochem Cycles 1:31-48

Reigstad M, Wassmann P, Riser CW, Øygarden S, Rey F (2002) Variations in hydrography, nutrients and chlorophyll $a$ in the marginal ice-zone and the central Barents Sea. J Mar Syst 38:9-29

Ringuette M, Fortier L, Fortier M, Runge JA, Bélanger S, Larouche P, Weslawski JM, Kwasniewski S (2002) Advanced recruitment and accelerated population development in Arctic calanoid copepods of the North Water. Deep-Sea Res II 49:5081-5099

Romero N, Silverberg N, Roy S, Lovejoy C (2000) Sediment trap observations from the Gulf of St. Lawrence and the continental margin of eastern Canada. Deep-Sea Res II 47 : $545-583$

Sampei M, Sasaki H, Hattori H, Kudoh S, Kashino Y, Fukuchi $M(2002)$ Seasonal and spatial variability in the flux of biogenic particles in the North Water, 1997-98. Deep-Sea Res II 49:5245-5257

Editorial responsibility: Otto Kinne (Editor), Oldendorf/Luhe, Germany
Shindell DT, Miller RL, Schmidt GA, Pandolfo L (1999) Simulation of recent northern winter climate trends by greenhouse-gas forcing. Nature 399:452-455

Smayda TJ (1970) The suspension and sinking of phytoplankton in the sea. Oceanogr Mar Biol A Rev 8:353-414

Smayda TJ (1971) Normal and accelerated sinking of phytoplankton in the sea. Mar Geol 11:105-122

Smayda TJ (1978) From phytoplankton to biomass. In: Sournia A (ed) Phytoplankton manual. UNESCO, Paris, p 273-279

Smith M, Rigby B (1981) Distribution of polynyas in the Canadian Arctic. In: Stirling I, Cleator H (eds) Polynyas in the Canadian Arctic. Can Wildl Serv Occas Pap 45, Canadian Wildlife Service, Ottawa, p 7-29

Smith SD, Muench RD, Pease CH (1990) Polynyas and leads: an overview of physical processes and environment. J Geophys Res 95:9461-9479

Sokal RR, Rohlf FJ (1981) Biometry: the principles and practice of statistics in biological research, 2 nd edn. WH Freeman, San Francisco, CA

Stirling I (1980) The biological importance of polynyas in the Canadian Arctic. Arctic 33:303-315

Stirling I (1997) The importance of polynyas, ice edges, and leads to marine mammals and birds. J Mar Syst 10:9-21

Stouffer RJ, Manabe S, Bryan K (1989) Interhemispheric assymetry in climate response to a gradual increase of atmospheric $\mathrm{CO}_{2}$. Nature 342:660-662

Tremblay JÉ, Gratton Y, Fauchot J, Price NM (2002a) Climatic and oceanic forcing of new, net, and diatom production in the North Water. Deep-Sea Res II 49:4927-4946

Tremblay JÉ, Gratton Y, Carmack EC, Payne CD, Price NM (2002b) Impact of the large-scale Arctic circulation and the North Water Polynya on nutrient inventories in Baffin Bay. J Geophys Res 107:10.1029/2000JC000595

Volk T, Hoffert MI (1985) Ocean carbon pumps: analysis of relative strengths and efficiencies in ocean driven $\mathrm{CO}_{2}$ changes. In: Sundquist ET, Broecker WS (eds) The carbon cycle and atmospheric $\mathrm{CO}_{2}$ : natural variations archean to present. AGU Monograph 32, American Geophysical Union, Washington DC, p 99-110

Waite A, Bienfang PK, Harrison PJ (1992a) Spring bloom sedimentation in a subarctic ecosystem. I. Nutrient sensitivity. Mar Biol 114:119-129

Waite A, Bienfang PK, Harrison PJ (1992b) Spring bloom sedimentation in a subarctic ecosystem. II. Succession and sedimentation. Mar Biol 114:131-138

Wassmann P (1989) Sedimentation of organic matter and silicate from the euphotic zone of the Barents Sea. Rapp P-v Réun Cons Int Explor Mer 188:108-114

Wassmann P, Vernet M, Mitchell BG, Rey F (1990) Mass sedimentation of Phaeocystis pouchetii in the Barents Sea. Mar Ecol Prog Ser 66:183-195

Wassmann P, Peinert R, Smetacek V (1991) Patterns of production and sedimentation in the boreal and polar Northeast Atlantic. Polar Res 10:209-228

Yager P, Wallace WR, Johnson KM, Smith WO Jr, Minnett PJ, Deming JW (1995) The Northeast Water Polynya as an atmospheric $\mathrm{CO}_{2}$ sink: a seasonal rectification hypothesis. J Geophys Res 100:4389-4398

Submitted: March 4, 2004; Accepted: July 27, 2004 Proofs received from author(s): November 15, 2004 